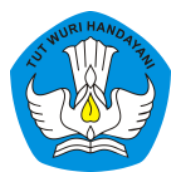

Page: $357-370$

\title{
Pengembang Media Pembelajaran Aquaponik-Induksi Elektromagnetik untuk Meningkatkan Literasi Sains Siswa Melalui Pembelajaran Berbasis STEM
}

\author{
Abdul Aziz Rahman \\ Sekolah Menengah Pertama Negeri 2 Kadudampit \\ Email:m.subkiajizi@gmail.com
}

Published: Juli 30, 2020

Article Url: http:/ / ojsdikdas.kemdikbud.go.id/index.php/didaktika/article/view/129

\begin{abstract}
Science learning for middle school students is still a scary figure. The many terms, abstract concepts, and formulas make it difficult for students to learn science. This has an impact on the achievement of student learning success is low. The purpose of obtaining aquaponic-electromagnetic induction learning media is to increase students' scientific literacy through STEM-based learning. The method used in this research is the $4 D R \mathcal{E D}$ model ((define, design, develop, and essiminate). Data were collected using media expert content validation sheets, science literacy questions, and student response questionnaires. The results showed that the level of media validity Aquaponic-electromagnetic induction in CVI is 0.86 (valid) Scientific literacy achievement of experimental class students has higher average score compared to students in the control class Students respond positively to electromagnetic induction aquaponic media. AIGO media can be used to improve Student literacy through STEM based learning.
\end{abstract}

Keywords: Aquaponics-Induction, Magnetic, Learning Media, STEM, Science Literacy 


\begin{abstract}
Abstrak
Pembelajaran IPA bagi siswa SMP masih menjadi sosok menakutkan. Banyaknya istilah, konsep abstrak, dan rumus membuat siswa merasa sulit belajar IPA. Hal ini berimbas pada pencapaian keberhasilan belajar siswa yang rendah. Tujuan memperoleh media pembelajaran aquaponik-induksi elektromagnetik untuk meningkatkan literasi sains siswa melalui pembelajaran berbasis STEM. Metode yang digunakan pada penelitian ini adalah RED model $4 D$ ((define, design, develop, dan dessiminate)..Data dikumpulkan dengan menggunakan lembar validasi konten ahli media, soal literasi sains, dan angket tanggapan siswa, Hasil penelitian menunjukkan bahwa tingkat validitas media aquaponik-induksi elektromagnetik pada CVI sebesar 0,86 (valid). Capaian literasi sains siswa kelas eksperimen memiliki rata-rata capaian skor lebih tinggi dibandingkan dengan siswa pada kelas kontrol. Siswa menanggapi positif terhadap media aquaponik-induksi elektromagnetik. Berdasarkan hasil penelitian diperoleh bahwa media AIGO dapat digunakan untuk meningkatkan literasi Siswa melalui pembelajaran berbasis STEM.
\end{abstract}

Keywords: Aquaponik-Induksieletromagnetik, Media Pembelajaran, STEM, Literasi Sains

\title{
A. Pendahuluan
}

National Research and Council (NRC) mengungkap pentingnya mengintegrasikan Technology, Engeenering, and Mathematics pada pembelajaran IPA untuk menghadapi tantangan Revolusi Industri 4.0 dan tuntutan kerja abad 21 (Harwell, 2015). Pendekatan pembelajaran yang mengintegrasikan teknologi, teknik, dan matematika dalam lingkup IPA dikenal dengan pendekatan STEM. Untuk mencapai keterpaduan STEM tersebut, maka pemilihan model dan media pembelajaran sangatlah penting. Model pembelajaran yang dipandang mampu secara efektif memperpadukan STEM adalah model pembelajaran project based learning (Dwidevi, 2014). Selain itu, penggunaan media pembelajaran dalam pembelajaran IPA patut menjadi perhatian. Media pembelajaran dapat memudahkan siswa dalam memahami dan mengingat istilah, hukum, rumus dan konsep abstrak IPA (Jager, 2012). 
Selama ini, pembelajaran IPA bagi siswa SMP masih menjadi sosok menakutkan. Banyaknya istilah, konsep abstrak, dan rumus membuat siswa merasa sulit belajar IPA. Hal ini berimbas pada pencapaian keberhasilan belajar siswa yang rendah. Senada dengan hal tersebut, penilaian yang dilakukan oleh PISA (Program International for Student Assessment) pada tahun 2015 menunjukkan pencapaian siswa di Indonesia cukup rendah. Indonesia berada pada peringkat 63 dari 65 negara peserta. Pada tingkat tersebut capaian siswa dapat dikategorikan masih rendah pada kemampuan berfikir tingkat tinggi (Martin \& Michel O, 2012). Untuk memperoleh peningkatan kemampuan literasi sains siswa, maka mutlak pembelajaran sains harus menyenangkan, menuntut siswa untuk memahami istilah dan penerapan rumus melalui serangkaian percobaan, dan belajar secara konstektual untuk konsep-konsep yang abstrak.

Konsep abstrak dalam penilaian PISA melibatkan isu-isu yang penting dalam kehidupan sehari-hari (Toharudin, Hendrawati, \& Rustaman, 2011). Isu-isu lingkungan yang terjadi saat ini begitu beragam. Teknologi dan aktivitas manusia telah mempengaruhi sebagian besar ekosistem. Manusia telah mengganggu struktur tropik pada ekosistem pada sebagian besar wilayah dunia (Campbell, Recce \& Mitchell, 2002). Daur energi terjadi pada makhluk hidup melalui rantai makanan. Perolehan energi dimulai dari tumbuhan sebagai produsen. Interaksi tumbuhan dengan lingkungan melalui fotosintesis menghasilkan energi. Energi dari tumbuhan dimanfaatkan hewan herbivor. Terjadilah daur energi dari tingkat trofik produsen $\rightarrow$ konsumen tingkat satu (hewan herbivor) $\rightarrow$ konsumen tingkat dua (hewan herbivor) $\rightarrow$ detrivor (pengurai bahan organik menjadi anorganik) $\rightarrow$ produsen (tumbuhan). Daur energi juga terjadi pada benda tidak hidup. Salah satu contohnya 
adalah pemanfaatan energi alternatif untuk pembangkit listrik. Pembangkit listrik memanfaatkan Gaya Gerak Listrik (GGL) induksi merupaka salat satu solusi untuk menanggulangi pembakaran bahan bakar fosil yang dapat merusak lingkungan untuk pembangkit listrik.

Kemampuan literasi sains siswa pada konsep daur energi sangat penting. Daur energi menjadi salah satu topik utama dunia. Penggunaan bahan bakar untuk pembangkit listrik menyebabkan efek domino bagi kerusakan lingkungan. Kesadaran akan pentingnya pemanfaat energi secara optimal dan penggunaan energi alternatif dalam rangka menjaga kelestarian lingkungan hidup perlu dipahami siswa sejak dini.

Pembelajaran berbasis STEM dengan menggunakan media aquaponik-induksi elektromagnetik dipandang dapat menjadi solusi untuk menjawab permasalahan yang mengemukakan Pembelajaran STEM diajarkan dengan menampilkan contoh media aquapopnikinduksielektromagnetik. Siswa merumuskan masalah, menentukan variabel, melakukan percobaan, dan menyimpulkan hasil percobaannya. Selanjutnya, siswa dibimbing untuk merancang proyek pembuatan media aquaponik-induksi elektromagnetik secara berkelompok. Siswa merancang alat, mengujicoba alat, melakukan percobaan dengan alat yang dibuat, membuat tabel pengamatan, dan menyajikan kesimpulan dalam bentuk grafik atau gambar berdasarkan data yang diperoleh. Dengan demikian, pembelajaran STEM dengan menggunakan media aquaponik-induksi elektromagnetik diharapkan dapat meningkatkan literasi sains siswa pada tema daur energi

Penelitian media aquaponik untuk meningkatkan hasil belajar siswa telah dilaksanakan oleh Aminin pada tahun 2019. Hasil-hasil penelitiannya menunjukkan bahwa pembelajaran dengan menggunakan 
aquaponik dapat meningkatkan hasil belajar siswa secara individu maupun klasikal pada konsep filtrasi air. Persentase hasil belajar secara individu sebesar $75 \%$. Siswa terlihat sangat tertarik dan antusias terhadap pembelajaran (Aminin, 2019).

Agar pelaksanaan penelitian terperinci dan terarah, maka dijabarkan melalui beberapa tahapan. Tahap Pertama, validitas media aquaponik-induksi elektromagnetik melalui pembelajaran berbasis STEM pada tema daur energi. Tahap Kedua, profil literasi sains siswa pada tema daur energi melalui pembelajaran berbasis STEM menggunakan media aquaponik-induksi elektromagnetik. Dan Tahap Ketiga, tanggapan siswa terhadap penggunaan aquaponik-induksi elektromagnerik pada pembelajaran STEM.

Sehingga akan terlihat yang hendak dicapai yaitu karya inovasi ini sebagai berikut; 1) Memperoleh media aquaponik-induksi elektromagnetik yang valid untuk pembelajaran berbasis STEM pada tema daur energy; 2) Peningkatan literasi sains pada tema daur energi melalui pembelajaran berbasis STEM menggunakan media aquaponik-induksi elektromagnetik; 3) Tanggapan siswa terhadap pengguna aquaponikinduksi elektromagnetik pada pembelajaran STEM. Penelitian ini diharapkan dapat memberikan manfaat bagi guru dapat memperoleh media pembelajaran yang valid untuk mempelajari konsep abstrak pada tema daur energi. Manfaat lainnya adalah siswa mengetahui profil kemampuan literasi sains pada tema daur energi. Siswa memperoleh pengalaman belajar dengan menggunakan pembelajaran berbasis STEM menggunakan media aquaponik-induksi elektromagnetik. 


\section{B. Metode}

Penelitian dilakukan menggunakan tahapan penelitian pengembangan (Research and Development) model 4D yaitu Define, Design, Develop, dan Disseminate (Thiagarajan \& Sivasailam, 1974) dapat dijelaskan sebagai berikut: Define (Pendefinisian) Pada tahapan ini dilakukan halhal sebagai berikut: Melakukan analisis standar isi mata pelajaran tema daur energi. Pada penyusunannya, media pembelajaran disesuaikan dengan indikator kompetensi literasi sains disusun berdasarkan hasil pengkajian dari berbagai literatur dan di-judgement oleh ahli. Selain itu, indikator tersebut harus sesuai dengan tuntutan Standar Kompetensi Lulusan (SKL) Kurikulum 2013. Melakukan studi kepustakaan mengenai pengembangan media pembelajaran. Melakukan studi kepustakaan mengenai pembelajaran dan penilaian literasi sains. Melakukan analisis kompetensi literasi sains yang mencakup: mengidentifikasi masalah, menjelaskan fenomena ilmiah, dan menggunakan bukti ilmiah pada konsep Interaksi makhluk hidup dan lingkungannya. Perumusan indikator dan tujuan pembelajaran melalui telaah konten, konteks, dan kompetensi.

Design (Perancangan), pada tahap design dilakukan hal-hal sebagai berikut: Membuat desain media; Melakukan validasi media; Melakukan revisi media pembelajaran; Melakukan uji coba butir soal literasi sains; Memperbaiki soal literasi sains; Menentukan kelas yang akan dijadikan subjek penelitan..

Develop (Pengembangan), pada tahap develop dilakukan hal-hal sebagai berikut: Mengimplementasikan media aquaponik-induksi elektromagnetik pada pembelaran STEM; Menyebar angket pada siswa.; Melakukan wawancara terstruktur dengan siswa. 
Disseminate (Menyebarkan), pada tahap desiminasi dilaksanakan dengan mendistribusikan informasi secara terbatas media aquaponikinduksielektromagnetik pada pembelajaran berbasis STEM pada rekan sejawat di sekolah dan simposiun nasional.

\section{Hasil dan Pembahasan}

Peningkatan kemampuan literasi sains siswa, maka mutlak pembelajaran sains harus menyenangkan untuk memahami istilah dan penerapan rumus melalui serangkaian percobaan, dan belajar secara konstektual untuk konsep-konsep yang abstrakm maka telah dilakukan:

\section{Validitas Media Aquaponik-induksi elektromagnetik}

Media aquaponik-induksi elektromagnetik merupakan media yang terdiri dari aquaponik (daur energi pada makhluk hidup) dan pembangkit listrik dengan ggl induksi (daur energi pada benda tak hidup) yang disatukan menjadi media yang tidak terpisahkan. Bahanbahan untuk membuat media ini memanfaatkan barang-barang bekas yang mudah ditemui.

Bahan aquaponik terdiri dari aquarium, kayu, pipa paralon bekas, dan pompa air. Sedangkan bahan lainnya seperti sendok plastik bekas, kayu, dinamo, kabel dirangkai menjadi pembangkit listrik tenaga air. Aquarium disimpan pada bagian dasar. Disusun rangka kayu untuk penyangga aquarium, hidroponik, dan pembangkit listrik. Pompa air ditempatkan pada aquarium dengan selang pembuangan air menuju ke bagian atas. Air mengalir melalui pipa dan kucuran air dari pipa ditangkap oleh sendok-sendok yang dirangkai khusus.

Perputaran rangkaian sendok tersebut akan menggerakan dinamo pembangkit listrik. Air dari pembangkit listrik ditampung pada ember 
kemudian air mengalir pada hidroponik. Air yang mengandung unsur organik mengalir pada kanal-kanal hidroponik sehingga diserap unsur organiknya oleh tumbuhan. Air kembali ke aquarium dalam keadaan bersih dari unsur organik.

Tujuan yang hendak dicapai dalam pembelajaran menggunakan media aquaponik-induksi elektromagnetik yaitu siswa dapat melakukan penyelidikan terhadap daur energi pada makhluk hidup dan benda tak hidup. Dari hasil penyelidikan siswa dapat membuat prototif aquaponik dan pembangkit listrik sederhana. Pembelajaran ini memberikan pengalaman kepada siswa dalam merancang, melakukan penyelidikan, dan menarik kesimpulan berdasarkan data empiris pengamatan.

Berdasarkan pertimbangan seleksi alternatif di atas, jenis inovasi pembelajaran pada penelitian ini adalah menginovasi media pembelajaran dengan mempertimbangan indikator pencapaian literasi sains sebagai tujuan pembelajarannya. Sementara itu pembelajaran dikemas dalam pembelajaran berbasis proyek dan mengaitkan kegiatannya dalam lingkup STEM. Rancangan media aquaponik-induksi elektromagnetik sebagai berikut:

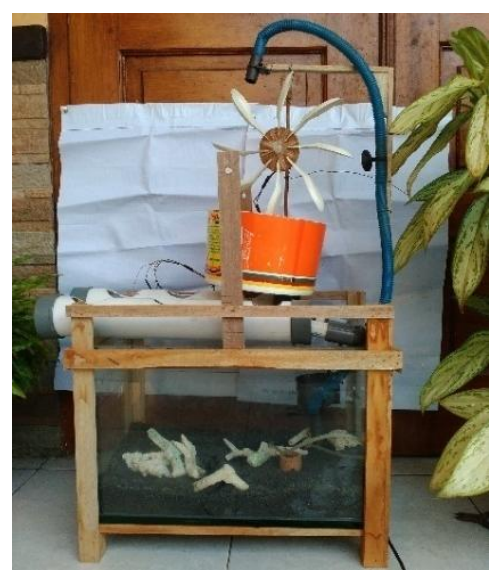

Gambar 1.

Media aquaponik-induksi elektromagnetik 
Media aquaponik-induksielektromagnetik memiliki kelebihan diantaranya 1) Bahan-bahan yang digunakan mudah untuk di dapat; 2) Media ini cukup ekonomis dalam penyusunannya; 3) Media ini dapat dirangkai oleh guru bahkan oleh siswa; 4) Media ini memberikan gambaran yang menyeluruh tentang konsep-konsep dalam tema daur energi. Namun masih terdapat beberapa hambatan dalam pelaksanaanya dalam pembelajaran diantaranya: Konten bahan ajar dapat lebih umum, sehingga peserta didik harus diarahkan untuk berfikir lebih spesifik; Pengkayaan materi ajar menuntut alokasi waktu yang lebih banyak, sementara sekolah tetap harus mematuhi kalender akademik; Kompetensi profesionalisme guru yang belum memenuhi kualifikasi akan menghambat implikasi media aquaponik-induksielektromagnetik berbasis literasi sains ini dalam pembelajaran; Keterbatasan pengetahuan guru tentang literasi sains, sebagai akibat proses sosialisasi yang tidak menyeluruh, menyebabkan guru tidak faham sistem asesmen internasional seperti PISA sehingga materi ajar tidak berkembang.

Validitas bahan ajar diuji oleh tujuh orang praktisi pendidikan yang sudah berpengalaman. Pengujian validitas konten tersebut bertujuan untuk memperoleh informasi mengenai kesesuaian konten bahan ajar digital dengan tahapan pembelajaran berbasis proyek. Hasil validasi dari tujuh dikemukakan sebagaimana tabel berikut ini:

Tabel 1.

Rekapitulasi Nilai CVR

\begin{tabular}{|l|c|c|}
\hline \multirow{2}{*}{ Indikator } & \multicolumn{2}{|c|}{ Kesesuaian } \\
\cline { 2 - 3 } & Ya & Tidak \\
\hline Kemudahan penyediaan alat & 7 & 0 \\
\cline { 2 - 3 } & 6 & 1 \\
\cline { 2 - 3 } & 7 & 0 \\
\hline Kemudahan dalam merangkai alat & 7 & 0 \\
\cline { 2 - 3 } & 6 & 1 \\
\hline
\end{tabular}




\begin{tabular}{|l|c|c|}
\hline \multirow{2}{*}{ Indikator } & \multicolumn{2}{|c|}{ Kesesuaian } \\
\cline { 2 - 3 } & Ya & Tidak \\
\cline { 2 - 3 } & 7 & 0 \\
\cline { 2 - 3 } & 6 & 1 \\
\hline Kemudahan dalam mengoperasikan alat & 7 & 0 \\
\cline { 2 - 3 } & 6 & 1 \\
\cline { 2 - 3 } & 6 & 1 \\
\hline
\end{tabular}

Validitas media aquaponik-induksi elektromagnetik berada pada nilai CVI sebesar 0,86. Berdasarkan kriteria validitasi pada tabel dapat disimpulkan bahwa media aquaponik-induksi elektromagntik valid pada semua indikator validitas media.

\section{Profil Literasi Sains Siswa}

Peningkatan kemampuan literasi sains pada masing-masing pra post test dapat dilihat pada Tabel 2. Nilai N-gain pratest dan posttest adalah 0,36. Nilai tersebut kemudian dikategorikan sejauh mana peningkatannya. Uji gain dihitung secara manual dengan rumus sebagai berikut:

$$
(g)=\left(\%\left(S_{f}\right)-\left(S_{i}\right)\right) /\left(100 \%-\left(S_{i}\right)\right)
$$

Keterangan

$g=$ Gain

Sf $=$ Skor Posttest

Si $=$ Skor pretest

Klasifikasi (kategori) N-Gain menurut Hake (1998) dapat dilihat pada tabel berikut ini:

Tabel 2.

Kategori N-Gain

\begin{tabular}{|l|l|}
\hline Rerata N-gain & Klasifikasi \\
\hline N-gain $>0,7$ & Tinggi \\
\hline $0,7>$ N-Gain $>0,3$ & Sedang \\
\hline $0,3>$ N-Gain & Rendah \\
\hline
\end{tabular}


Berdasarkan kategori yang tertera pada tabel 2. dapat diketahui bahwa nilai peningkatan kemampuan literasi sains pada penelitian ini termasuk ke dalam kategori sedang. Dengan demikian media aquaponikinduksielektromagnetik melalui pembelajaran berbasis STEM dapat meningkatkan kemampuan literasi sains pada kategori sedang.

Nilai rata-rata kemampuan literasi sain pada indikator-indikator dimensi proses dapat dilihat pada Tabel berikut ini:

Tabel 3.

Nilai Kemampuan Literasi Sains Pada Indikator-Indikator Dimensi Proses

\begin{tabular}{|l|l|l|l|}
\hline \multicolumn{1}{|c|}{ Indikator } & $\begin{array}{c}\text { Mengidentifikasi } \\
\text { permasalahan } \\
\text { secara ilmiah }\end{array}$ & $\begin{array}{c}\text { Menjelaskan } \\
\text { fenomena } \\
\text { ilmiah }\end{array}$ & $\begin{array}{c}\text { Menggunakan } \\
\text { bukti ilmiah }\end{array}$ \\
\hline Nilai & 58,6 & 65,5 & 64,6 \\
\hline Nilai Rata-rata & 100 & 88,9 & 95,0 \\
\hline Nilai min & 20,0 & 55,6 & 60,0 \\
\hline
\end{tabular}

Kemampuan literasi pada indikator menjelaskan fenomena ilmiah memiliki nilai rata-rata lebih tinggi dibandingkan indikator lainnya. Berdasarkan data hasil posttest siswa. Pada indikator ini memiliki capaian rata-rata di atas 50\% (lampiran analisis data posttest). Soal pada indikator ini mengarahkan siswa untuk mengenali fenomena yang terjadi melalui data-data ilmiah. Data diperoleh melalui observasi dan percobaan.

Dengan demikian, pembelajaran STEM menggunakan media aquaponikinduksi elektromagnetik cukup berhasil untuk memperkuat kemampuan siswa pada indikator menjelaskan fenomena ilmiah. Melalui pembelajaran STEM menggunakan media aquaponik-induksielektromagnetik, siswa lebih banyak untuk belajar aktif. Siswa diberikan keleluasaan untuk mencoba, mendesain, dan menghasilkan produk. Siswa memadukan kemampuannya dalam sains, 
matematika, dan teknologi untuk membuat sebuah desain pemecahan masalah. Kegiatan-kegiatan yang melibatkan siswa secara aktif menumbuhkan kepercayaan diri dan motivasi belajar siswa. Sebagaimana terdapat pada data angket siswa bahwa pembelajaran STEM dengan media aquaponik-induksielektromagnetik memberikan motivasi untuk belajar dan mengerjakan tugas dengan baik Hal ini diperkuat dengan temuan Dwidevi bahwa model pembelajaran yang dipandang mampu secara efektif memperpadukan STEM adalah model pembelajaran project based learning (Dwidevi, 2014).

\section{Tanggapan Siswa}

Untuk memperoleh gambaran tanggapan siswa terhadap pembelajaran maka disusunlah instrumen angket dan menyebarkannya kepada siswa setelah pembelajaran selesai. Data hasil angket tercermin pada grafik berikut ini:

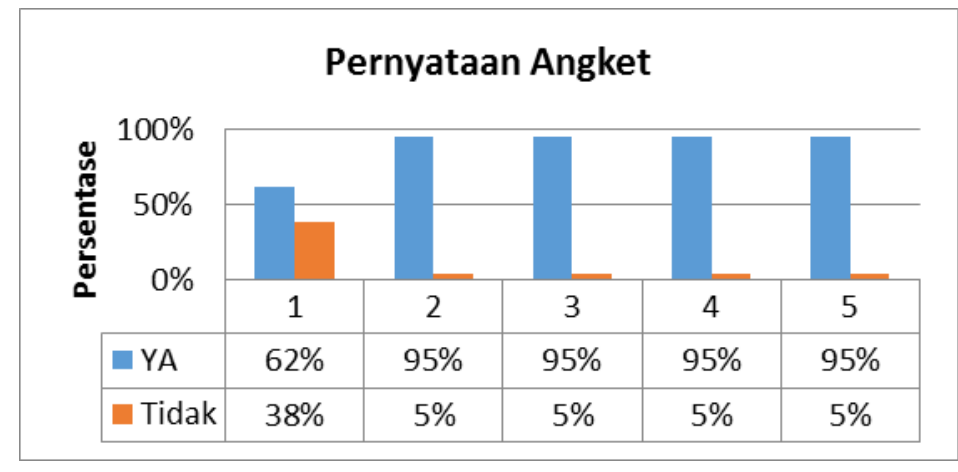

Gambar 4

Grafik tanggapan siswa

Keterangan:

(1) merupakan hal yang baru

(2) ketertarikan siswa pada pembelajaran

(3) Mendorong pengerjaan tugas dengan baik

(4) Membuat siswa termotivasi,

(5) Meningkatkan keinginan untuk belajar 
Berdasarkan data hasil angket menunjukkan bahwa sebagian besar siswa sepakat bahwa pembelajaran berbasis STEM dengan media aquaponik-induksi elektromagnetik merupakan hal yang baru, mendorong mengerjakan tugas dengan baik, memotivasi mereka, dan meningkatkan keinginan untuk belajar.

\section{Penutup}

Berdasarkan hal yang telah diuraikan dapat disimpulkan media aquaponik-induksi elektromagnetik memiliki tingkat validitas sebesar 0,86 (valid) untuk pembelajaran berbasis STEM pada tema daur energi. Kemudian media aquaponik-induksi elektromagnetik dapat meningkatkan literasi sains siswa melalui pembelajaran berbasis STEM. Siswa menanggapi positif terhadap implementasi Media aquaponik-induksi elektromagnetik melalui pembelajaran berbasis STEM meskipun dalam pelaksanaannya masih memiliki keterbatasan.

\section{UCAPAN TERIMA KASIH}

Peneliti ucapkan terimakasih kepada Kepala SMPN 2 Kadudampit, PPPPTK IPA Bandung, dan Direktorat Guru Dan Tenaga Kependidikan.

\section{DAFTAR PUSTAKA}

Campbell, N., Reece, J., \& Mitchell, L. (2002). Biologi Jilid III. Jakarta: Erlangga.

Dwidevi. (2014). Project Based Learning for STEM (Science, Technology,. International Conference and Advance Agile Manufacturing. USA: Oakland University 
Hake, R. R. (1998). Interactive-engagement versus traditional methods: A sixthousand-student survey of mechanics test data for introductory physics courses. American journal of Physics, 66(1), 64-74.

Harwell. (2015). Study of STEM Assessment in Engineering, Science, and Mathematic for Elementary and Middle School Students. School Science and Mathematic , 2.

Herlina, Herlina, \& Cici. (2006). Alat peraga. Jurnal pendidikan IPA .

Jager, T. d. (2012). Using Visual Media to Enhance Science Teaching and Learning in. DOI , 1-6.

Lawshe, C. H. (1975). Quantitative Approach to Content Validity. Personal Phsycology , 563-575.

Martin, \& Michel O. (2012). TIMSS 2011 International Research in Science. USA : TIMSS \& PILRS International Study Center and IEA.

Thiagarajan, \& Sivasailam. (1974). Instructional Development for Training Teacher Exptional Children. Washington DC: National Center for Improvement Educational.

Thomas, J. (2000). A Review Research on Project Based Learning. California: Autodesk Foundation.

Tohaeudin, Hendrawati, S., \& Rustaman, A. (2011). Membangun Literasi Peserta Didik. Bandung: Humaniora. 